\title{
Effect of diffuse pollution on water quality in mountain forest streams
}

\begin{abstract}
Agriculture is the main source of surface and groundwater pollution. It increases suspended solids and organic matter concentration with the subsequent eutrophication. Citrus and sugarcane are the predominant crops in the subtropical area under study and the agrochemicals used in different periods of the year. This study was carried out taking into consideration main regional drivers as well as precipitation regime (seasonal rains) and ground conditions. Two monitoring sites were established: one that reflected conditions not affected by agricultural activities (upper watershed) and another affected by agricultural diffuse pollution (downstream) in the middle of the watershed. The Seco and Famaillá rivers show the effects of diffuse pollution caused by land use. There is a differential impact in river water quality that depends on the proportion of altered basins, riparian forest and kind of crop. Even though the measured physicochemical variables do not go beyond the established limits to be classified as contaminants, these monitoring stations are useful in the determination of water variations due to diffuse pollution. Evidences of riparian forests benefits mitigating effects of agricultural use of the soil were observed.
\end{abstract}

Keywords: citrus crops, sugarcane crops, organic matter, water quality, riparian forest
Volume I Issue I - 2017

\author{
AK Garcia,' HR Fernandez, ${ }^{2}$ ML Rolandi, ${ }^{2}$ \\ L Gultemirian, ${ }^{2} \mathrm{~N}$ Sanchez, ${ }^{3} \mathrm{~L} \mathrm{Pla},{ }^{4} \mathrm{MV}$ \\ Hidalgo ${ }^{2}$ \\ 'Miguel Lillo Foundation, Institute of Quaternary Geology and \\ Paleoclimates, Argentina \\ ${ }^{2}$ Faculty of Natural sciences and IML-UNT, University in San \\ Miguel de Tucuman, Argentina \\ ${ }^{3}$ Faculty of Medicine, National University of Tucuman, Argentina \\ ${ }^{4}$ Department Agricultural Technology National University \\ Experimental Francisco de Miranda,Venezuela
}

Correspondence: AK Garcia, Miguel Lillo Foundation, Institute of Quaternary Geology and Paleoclimates, Argentina, Tel +54038I-1560334I5,Email karinaagarcia@yahoo.com

Received: April 18, 2017| Published: July 07, 2017

\section{Highlights}

a. Land use was observed in variation the concentration of 5 physicochemical variables.

b. Buffer strip (0-150m) affected for land use shows a diminished filter capacity.

c. Phosphate detected in water is attributed to the diminished capacity of the buffer strip.

d. Different fertilizers used in subtropical crops affect river water.

e. Riparian vegetation replacement in $>60 \%$ of affects ability to filter pollutants.

\section{Introduction}

Water is a vital resource for human life; hence, maintaining water quality is essential to ensure the viability of the ecosystem services it provides .Agriculture is one of the main land uses that affect water resources, influencing supply and quality of both surface water and groundwater. ${ }^{1}$ The so-called non-point source pollution or diffuse pollution causes changes in dissolved oxygen, distribution and concentration of major ions, conductivity and $\mathrm{pH} .{ }^{2,3}$ Diffuse pollution increases sediments and organic matter concentrations and provides pesticides. ${ }^{3,4}$ The amounts of nutrients (e.g. nitrogen and phosphorus compounds used in fertilizers) that can lead to eutrophication processes $^{2,5}$ are also increased. Eutrophication involves processes that lead to poor water quality and low aquatic ecosystem diversity due to oxygen loss around the world. ${ }^{6}$

The province of Tucumán, situated in the Northwest of Argentina, is one of the chief lemon producers in the world and it is also an important sugar cane producer. The main agrochemicals associated with these crops are nitrogen, phosphorus, potassium, iron, zinc, boron, copper and molybdenum. Their use and application times vary according to the kind of crop. The most common are nitrogen, phosphorus, and potassium as they are fundamental at the time of production, but they are the principal causes of eutrophication in aquatic media. ${ }^{7}$ It is well known that native riparian vegetation works as buffer zones, reducing the nutrients that go into the water. ${ }^{8-11}$ The buffer of riparian strip efficiency is determined by plant species composition, slope, width and precipitation regime among other factors (Gregory et al. 1991). Relationships between intensity, type of land use and buffering effect of the riparian strip on diffuse pollution is unknown in the Argentinean Northwes. ${ }^{12,13}$ The techniques and methods of landscape ecology with satellite images and the geographic information system help in the studies of buffer areas to reduce the harmful effects of current agricultural practices on river water quality. ${ }^{14,15}$ The aim of the present study is to determine the influence of agriculture on water quality in subtropical rivers by evaluating land use parameters and nutrient concentrations in river waters. We used the almost pristine mountain watersheds as reference areas. Our hypothesis is that subtropical crops alter the physicochemical characteristics of surface water.

\section{Materials and methods}

\section{Study area}

The study was conducted in the province of Tucumán, northwestern Argentina. Five watersheds were selected: Jaya, Solco, Seco, Pueblo Viejo and Famailla Rivers (Figure 1). These watersheds have similar characteristics in terms of native vegetation, crop area, average discharge, geology and soils (Table 1).

Topographic units in the province include the plains area to the east and a mountain range to the west, with an approximate altitudinal range of 300 to 5000 masl. Due to the presence of the mountain range, the climate is subtropical humid, with markedly seasonal orographic precipitations (1000/1500mm annually) and important contributions of fog during the dry season. ${ }^{16,17}$ The topographic characteristics and 
precipitation regimes result in an extensive west-southeast drainage network across the province. This hydrological system flows into the Salí-Dulce River, an endorheic watershed that extends through three provinces and comprises $89936 \mathrm{~km}^{2}$. Springs of Salí-Dulce River are located in the Nevados Del Aconquija mountain range ( $>4000$ masl) and drain an extensive area of mountain forest called Yungas. The Yungas (mountain rainforest) region is an area of varied topography, ranging from rainforest to misty pastures. Following the altitudinal gradient, the forest is classified as premontane lowland forest (400$700 \mathrm{~m})$, lower mountain forest $(700-1500 \mathrm{~m})$ and upper temperate montane forest (1500-2500m). ${ }^{17}$ Two other ecosystems extend farther up the altitudinal zones: cloud grasslands and highland Andean grasslands).$^{18}$ The premontane forest originally extended over a fertile subtropical plain that has been subjected to heavy anthropogenic activity and most of the native vegetation of the plain sector of the province has been replaced by crops and urban development.

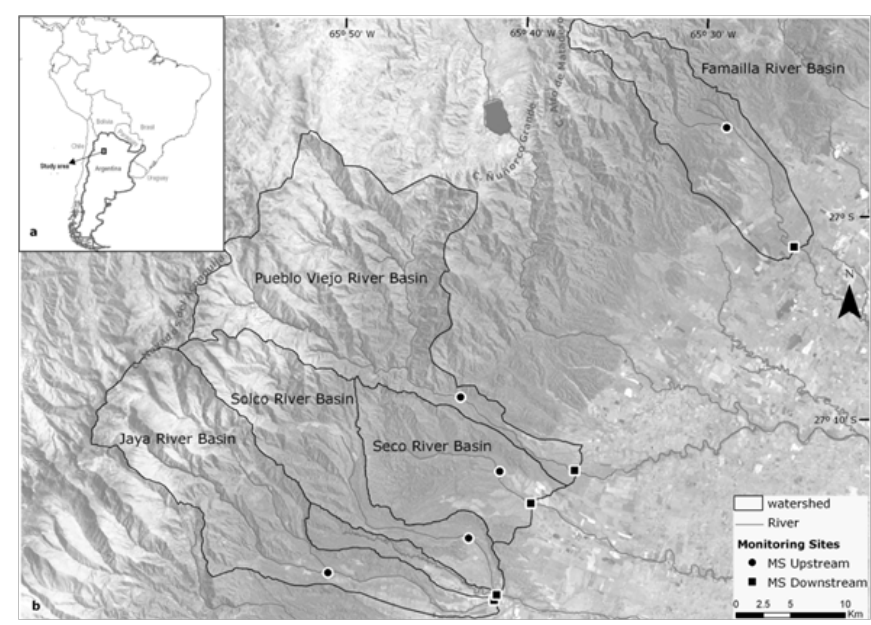

Figure I (A) Location of the study area in South America. (B) Location of watersheds and monitoring sites in the study area.

\section{Methodology}

Two sampling Monitoring Sites (MS), MS upstream (MSU) and MS downstream (MSD), were established in each watershed (Figure 2). MSU sampling sites revealed conditions of the upper watershed and were used as reference sites (i.e. not affected by agricultural activities). They were characterized by native vegetation (lower mountain forest, upper temperate montane forest, and grasslands). MSD sampling sites were located in the middle of each watershed and exposed the effect of land use, the only non-point source of pollution in the area between the upstream and downstream stations; there are no urban or industrial developments in the area (Figure 3). This sector of the watersheds was originally characterized by premontane lowland forest and lower mountain forest vegetation. Elevation went from 480 to 810 masl in MSU and from 380 to 450masl in MSD.

\section{Analysis of land-cover types}

The analysis of land-cover types was made with 2008 images, Landsat 5 TM (Thematic Mapper 231-79, spatial resolution of 30m) and China-Brazil Earth Resources Satellite program (CBERS 2B HRC 173: of the orbit $130 \mathrm{E}$ and $130 \mathrm{~B}$, points 2 to 5 ; orbit $130 \mathrm{C}$ points 2,3 and 5 ; orbit $130 \mathrm{D}$, points 2 to 5 , panchromatic images of $2.5 \mathrm{~m}$ spatial resolution), provided by the National Institute of Space Research of Brazil (http://www.dgi.inpe.br/CDSR). We also used the Digital Elevation Model (DEM) from the shuttle radar topography mission
(htpp://SRTM.CSI.CGIAR.ORG). The images were georeferenced to Gauss-Krügger (POSGAR 94) Zone 3 and geometrically corrected with GPS field points. Landsat 5TM images were atmospherically corrected using the method of Dark Object Subtractions (Chaves, 1996; Song et al., 2001); this modification consists of the conversion of the Digital Number (value between 0 and 255 recorded by the satellite sensor) to radiance and reflectance ( 0 to 1$)$. Maps were generated using a supervised classification; training areas were identified by means of Landsat and CBERS 2B HRC images. Digital classification was done using 13 bands: bands $1-5$ and 7 of Landsat image (band 6 was discarded because it has a different resolution that corresponds to a thermal band); three bands obtained after processing DEM (elevation, slope and its exposure); three bands obtained from the procedure "Tasseled Cap" (brightness, greenness and wetness); and a band from the Normalized Vegetation Index (NDVI).

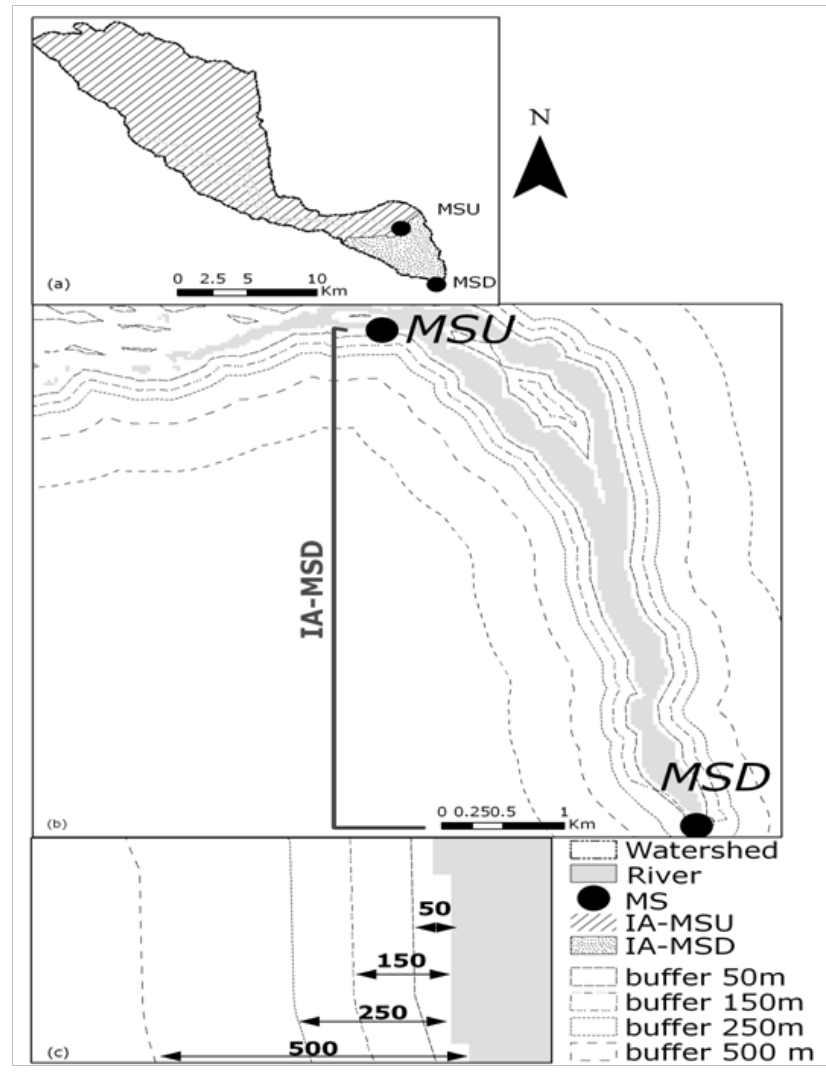

Figure 2 Schematized map of different landscape scales considered in this study. A) Watersheds and subdivisions and their influence areas in Monitoring Sites (IA-MS). B) Detail of the watershed sector considered as IA-MSD. C) Example of a detail of some riparian strips.

Classification was carried out with the Random Forest (RF) algorithm developed by ${ }^{19}$ with classification task of the R package. ${ }^{20}$ Random Forest algorithm has been identified as a suitable method for ecological studies. ${ }^{21-23}$ Four categories were defined for classification: preserved forest, highland grassland, bare soil and cropland. For the map, we used a filter with a 3 x 3-pixel window. Accuracy of maps was evaluated using a confusion matrix, employing a 1000x1000m grid.

With the map obtained, vegetation cover was estimated for each sampling site; each watershed was divided into two sectors using the elevation contour obtained from DEM and by visual interpretation in 
vector format with CBERS images using Arc Gis 9.2. The analysis of each watershed considered (Figure 2) an upper site (area of influence of the upstream monitoring site: AI-MSU) and a lower site (area between the upstream and downstream sites: AI-MSD). Visual interpretation was carried out to improve accuracy in the AI-MSD digitalization in vectorial format and to determine which crops were dominant in each watershed. Using satellite images, we determined different crop types (mostly sugar cane and lemon fruit), the proportion of native forest vs agricultural area, slope, and dominant cover types for riparian strips of different widths. To determine the impacts in water quality we analyzed nutrient concentration in five rivers with similar agricultural matrix, comparing them with reference sites. The proportion of native vegetation and crops, types of crops and the slope of cultivated land were determined with the cover map. In addition, riparian strips of different width categories: 50,100, 150, 200, 250, 500, 1000, and $>1000 \mathrm{~m}$ were calculated considering the river bed (bankfull width) as level zero (IA-MSD area in Figure 2). Finally, the proportion of vegetation cover and the slope in the riparian strip areas were estimated.

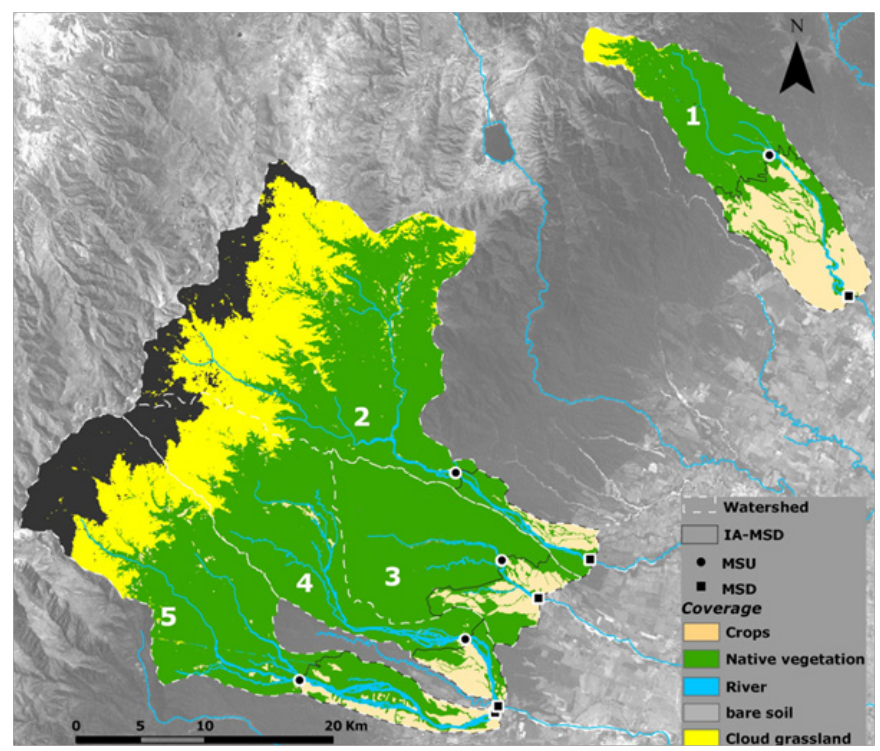

Figure 3 Land cover in the watersheds. Detail of cover type observed in the watersheds of I Famaillá River, 2 Pueblo Viejo River, 3 Seco River, 4 Solco River, 5 Jaya River.

\section{Physical and chemical analyses}

We took water samples for physical and chemical analyses every two months in 2009 and 2010 (11 total sample dates); stations were also sampled. Samples of surface water were taken with white high density propylene bottles (1liter) and stored without air bubbles. We also prepared blank samples for each survey, consisting of distilled water bottled in the field. All samples were collected, handled and preserved at the same time and in the same way. All samples were processed following standardized protocols of. ${ }^{24-26}$ Presence of any parameters in the field blank samples could indicate contamination during the sampling process or from sampling equipment and supplies. Deviation in parameters of the duplicate water samples could indicate contamination or incorrect sample processing.

Field measurements were carried out for dissolved oxygen with a Hach Senlon6 oximeter, conductivity with a pocket meter Hach
SenIon 156, pH using a Metrohm 826 Mobile, and total alkalinity with a colorimetric method. In the laboratory of Facultad de Ciencias Naturales \& "Miguel Lillo" Institute, Universidad National de Tucumán, we determined the following parameters: total solids, major ion composition (calcium, magnesium, sodium, chloride, sulfate, and bicarbonate) and nutrients (ammonia, nitrite, nitrate, phosphate and potassium) with error $<5 \%$. Bicarbonate was calculated using neutralization volumetry while major ion composition, nitrite and nitrate were established with ionic chromatography (Metrohm IC881) at constant temperature $\left(25^{\circ} \mathrm{C}\right)$. Ammonium was detected using the Nessler method and Phosphate was confirmed with the ascorbic acid method.

\section{Statistical analyses}

The influence of the environmental variables measured was analyzed by means of the Principal Component Analysis (PCA) with 11 samples from MSU and MSD of each river, including percentage of native riparian vegetation cover for each riparian strip, nutrients (ammonia, nitrite, nitrate, phosphate, and potassium) and total solids. To establish differences between reference areas (IA-MSU) and crop areas (IA-MSD) we compared MS of each river (intra-watershed comparison) with a paired t test analyzing variables associated with diffuse pollution (nutrients and total solids). To establish different degrees of land use, an inter-watershed comparison was carried out using an analysis of variance (ANOVA) of the diffuse pollution variables. It was done with a new variable calculated from concentration mean differences of each MS to test variance homogeneity.

\section{Results}

River water in the five watersheds was characterized as calcic bicarbonated, well oxigenated and with low total solids concentration. Conductivity revealed a slight salinization and nutrients concentration at each site during the study (Table 1). Watershed areas above the IAMSU (Figure 2) were covered by native vegetation. By contrast, areas above the IA-MSD were covered by a mean of $68 \%$ native vegetation and $32 \%$ crops (Figure $3 \&$ Table 1). Details about cultivated areas of IA-MSD are presented in Table 1. The comparison of the major density of the cultivated area $(>40 \%)$ in IA-MSD revealed that the highest dense areas in the riparian strips was in Famaillá River. Note for this river an area of $40 \%$ cultivated in $150 \mathrm{~m}$ of the riparian strip (Table 1). Main crop distributions (sugar cane and citric fruits) are shown in Table 2. Note that citrus fruits are predominant in Solco and Pueblo Viejo Rivers, while sugar cane prevails in Jaya River. On the other hand, Seco and Famaillá Rivers have an even crop distribution (Table 2). The multivariate analysis accounted for $90 \%$ of the total variability for the first two axes. The upstream sites were located on the left of axis 1 of the PCA plot, whereas all, except one of the downstream sites, were on the right side (Figure 4). Axis 1 was characterized by phosphates $\left(r^{2}=0.95\right)$, potassium $\left(r^{2}=0.93\right)$, nitrites $\left(r^{2}=0.90\right)$, TS $\left(r^{2}=0.97\right)$ and native vegetation $\left(r^{2}=0.94\right)$. In contrast, ammonium concentration of the second axis separates Seco River MSD from MSU (Figure 4). It is noted in Table 1 that nutrients were always higher in IA-MSD than MSU. T test analysis showed differences among diffuse pollution variables (Table 3). Famaillá River presented differences between $\mathrm{MS}$ in five variables $\left(\mathrm{NO}_{2}^{-}\right.$, $\mathrm{NH}_{4}^{+}$, TS, $\mathrm{K}^{+}$y $\mathrm{PO}_{4}^{3-}$ ). Seco and Pueblo Viejo Rivers were unlike in two variables $\left(\mathrm{K}^{+} \mathrm{y} \mathrm{PO}_{4}{ }^{3-}\right)$ while Solco differed in $\left(\mathrm{TS} \mathrm{y} \mathrm{NH}_{4}^{+}\right)($Table 
3). Jaya River was dissimilar in only one variable $\left(\mathrm{K}^{+}\right)(\mathrm{p}<0.007)$. ANOVA showed significant differences among rivers in potassium, phosphate and total solids (Table 4). Tukey test showed differences between Famaillá and all other rivers in potassium and total solids. Phosphate was significantly different in Famaillá when compared to Jaya and Seco Rivers. Anova does not revealed nitrogenous nutrients differences; they were similar in the studied rivers (Table 1) (Table 4). Significant differences were observed between dry and rainy periods for some ions as well as bicarbonate $(\mathrm{p}<0.0001)$, calcium $(\mathrm{p}=0.0001)$, magnesium $(\mathrm{p}=0.0021)$ and sodium $(\mathrm{p}=0.0083)$.
Table 2 Types of crop in percentage of each IA-MSD

\begin{tabular}{llll}
\hline IA-MSD & Sugar cane & Citric fruits & Other $^{\mathbf{a}}$ \\
\hline Solco & 4 & 46 & 0 \\
Seco & 24 & 20 & 1 \\
Pueblo Viejo & 5 & 21 & 4 \\
Jaya & 16 & 4 & 13 \\
Famailla & 26 & 28 & 14 \\
\hline
\end{tabular}

a, Blueberry, Forestry, Potato, etc

Table 3 Paired $t$ test for each river comparing MS and using nutrients and total suspended Solids $(p<0.05)$

\begin{tabular}{|c|c|c|c|c|c|c|c|c|c|c|}
\hline & \multicolumn{2}{|c|}{ Famailla } & \multicolumn{2}{|l|}{ Jaya } & \multicolumn{2}{|c|}{ Pueblo viejo } & \multicolumn{2}{|l|}{ Seco } & \multicolumn{2}{|c|}{ Solco } \\
\hline & $p$ & $t$ & $p$ & $t$ & $p$ & $t$ & $p$ & $t$ & $p$ & $\mathbf{t}$ \\
\hline $\mathrm{K}^{+}$ & 0 & -6.57 & 0.007 & -3.625 & 0.059 & -2.195 & 0.012 & -3.249 & 0.379 & -0.949 \\
\hline $\mathrm{NO}_{2}^{-}$ & 0.052 & -2.275 & 0.853 & 0.191 & 0.187 & -1.443 & 0.103 & -1.843 & 0.109 & -1.879 \\
\hline $\mathrm{NO}_{3}^{-}$ & 0.714 & -0.379 & 0.828 & -0.225 & 0.147 & 1.604 & 0.892 & -0.14 & 0.64 & 0.493 \\
\hline $\mathrm{NH}_{4}^{+}$ & 0 & -6.389 & 0.349 & -0.994 & 0.84 & -0.208 & 0.361 & -0.98 & 0.035 & -2.714 \\
\hline $\mathrm{PO}_{4}^{3-}$ & 0 & -7.63 & 0.521 & -0.672 & 0.051 & -2.298 & 0.023 & -2.799 & 0.136 & -1.724 \\
\hline TS & 0.004 & -4.069 & 0.934 & 0.085 & 0.846 & 0.201 & 0.233 & 0.233 & 0.006 & -4.171 \\
\hline
\end{tabular}

Table 4 Difference in nutrient content between rivers

\begin{tabular}{llll}
\hline & & & Test of homogeneity of variance \\
\hline & $\mathbf{P}$ & $\mathbf{F}$ & $\mathbf{P}$ \\
\hline $\mathrm{K}^{+}$ & $\mathbf{0 . 0 0 0 *}$ & 7.011 & 0.527 \\
$\mathrm{NO}_{2}{ }^{-}$ & 0.082 & 2.245 & 0.042 \\
$\mathrm{NO}_{3}{ }^{-}$ & 0.856 & 0.33 & 0 \\
$\mathrm{NH}_{4}^{+}$ & 0.652 & 0.618 & 0.608 \\
$\mathrm{PO}_{4}{ }^{3-}$ & $\mathbf{0 . 0 1 0} * *$ & 3.858 & 0.608 \\
$\mathrm{TS}^{+}$ & $\mathbf{0 . 0 0 0 * * *}$ & 6.737 & 0.063 \\
\hline
\end{tabular}

\begin{tabular}{|c|c|c|}
\hline \multicolumn{3}{|c|}{$\mathrm{PO}_{4}{ }^{3-}(* *)$} \\
\hline River I & River II & $p$ \\
\hline \multirow[t]{4}{*}{ Famaillá } & Jaya & 0.009 \\
\hline & Pueblo Viejo & 0.057 \\
\hline & Seco & 0.044 \\
\hline & Solco & 0.067 \\
\hline \multicolumn{3}{|l|}{ TS $(* * *)$} \\
\hline River I & River II & $p$ \\
\hline \multirow[t]{4}{*}{ Famaillá } & Jaya & 0.001 \\
\hline & Pueblo Viejo & 0.001 \\
\hline & Seco & 0.008 \\
\hline & Solco & 0.046 \\
\hline
\end{tabular}

$\mathrm{P}$ values from one-way Anova; ${ }^{*}$,* and ***multiple comparisons with $\mathrm{K}^{+}, \mathrm{PO}_{4}^{3-}$ TS

\begin{tabular}{lll}
\hline Multiple comparisons (HSD of Tukey) \\
\hline $\mathrm{K}^{+}(*)$ & \\
River I & River II & $P$ \\
Famaillá & Jaya & $\mathbf{0 . 0 0 I}$ \\
& Pueblo Viejo & $\mathbf{0 . 0 0 1}$ \\
& Seco & $\mathbf{0 . 0 3 5}$ \\
& Solco & $\mathbf{0 . 0 0 1}$ \\
\hline
\end{tabular}

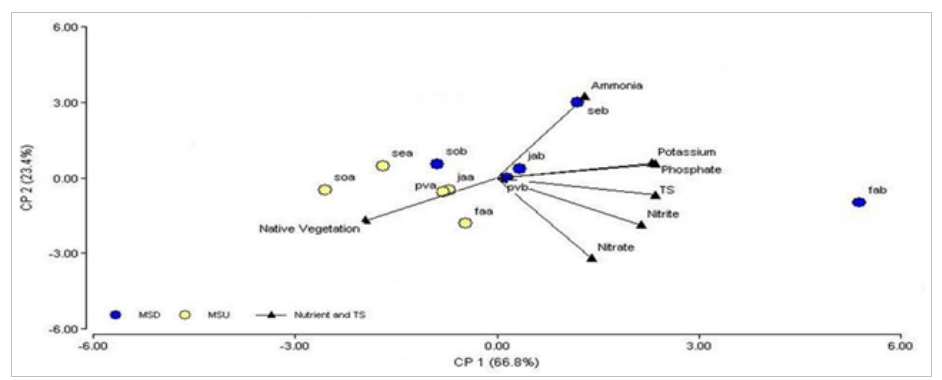

Figure 4 Principal component analysis-ordination triplot showing sampled sites and supplementary environmental variables as arrows. Highest nutrient concentration is observed in monitoring site downstream of Famaillá (fab) and Seco (seb) Rivers. 


\section{Discussion}

Our study confirmed that the presence of crops alters the physicochemical characteristics of water in watersheds with geographical features not considered before. However, crop type and intensity (quantity and riparian vegetation) alter surface water in different ways as observed..$^{15}$ The difference in potassium, nitrite, ammonia, phosphate and total solids concentrations observed between upstream and downstream stations of Famaillá Rivers was likely a consequence of the intense IA-MSD land use. The IA-MSD of Famaillá River presented the highest land use intensity, covering more than $60 \%$ of the area. The highest riparian strip land use observed in this river show the riparian zones effects, reducing nutrients entry. These results are consistent with other studies that have demonstrated the importance of native vegetation as a filter for nutrients and fine sediments..$^{27,28,4,14}$ According to ${ }^{29}$ native vegetation reduces the impact of crops on water quality; its efficiency varies depending on riparian strip width which ranged from 10 to $100 \mathrm{~m}$. The comparison of the density of the cultivated area in IA-MSD among Famaillá, Seco and Solco Rivers $(69 \%, 49 \%$ and $45 \%$ respectively) revealed that the less dense areas in the riparian strips of Seco and Solco Rivers were maximizing the potential reduction of nutrients and solids in water These two watersheds presented a less dense cultivated area in the $150 \mathrm{~m}$ riparian strip. Famaillá River presented higher intensity of land use in the riparian strip $(40 \%$ in the $0-150 \mathrm{~m})$ affecting the filter capacity of the buffer strip. ${ }^{30}$

Although the watersheds were relatively close (Figure 1) the suite of nutrients in the river waters was not similar probably due to the different fertilizers used on the crops (sugar cane and citric fruit). For example, Famaillá, Pueblo Viejo and Solco Rivers had similar phosphate concentrations because their citric plantation was $>21 \%$ vs Jaya River with $<4 \%$.On the other hand, although the citrus area in Seco River was 20\%, nutrient concentration differed from that of other rivers, probably because the citrus plantation included sour orange. The higher ammonium concentrations in Seco River AI-MSD may be related to the specific type of citric (sour orange). Nutrients quantities in studied rivers are not important at the present but some measures must be taken for government agencies such as sanctions and other also using natural mitigation process. ${ }^{15}$ In Tucuman, many anthropogenic activities such as cultivation in riparian areas and logging are forbidden by law in terrain with slopes above $10 \%$, because they are considered unsuitable practices with respect to soil conservation. In the watersheds studied, cultivated lands were characterized by a very modest slope $(<5 \%)$, while only $0.02 \%$ of the land cover was above that value (Famaillá and Jaya watersheds). The need to consider landscape characteristics such as slope in relation to water quality was reported by, ${ }^{31}$ who indicated that pollutant runoff from crop areas increased with increasing slope. In another river of Tucumán (Lules River watershed), with comparable elevation and environmental conditions, crops are cultivated in riparian areas and more than $50 \%$ are grown on lands with $10 \%$ slope. ${ }^{17,11}$ However, nutrient concentrations were always lower than those measured in the present study. ${ }^{32}$ This may be explained by less intensive practices in small crop fields by settled farmers in the Lules River watershed, ${ }^{33,11}$ compared with the more industrial agricultural practices in the five watersheds treated here. We attributed the differences observed to the more intensive use of manure in the industrial agricultural practices. However, only one of the five watersheds studied, with intensive land use, showed significant differences in five out of six variables measured $\left(\mathrm{NO}_{2}^{-}, \mathrm{NO}_{3}^{-} \mathrm{NH}_{4}^{+}, \mathrm{TS}, \mathrm{K}^{+}\right.$y $\left.\mathrm{PO}_{4}^{3-}\right)$. This difference can be attributed to the more intense use of the riparian strip in Famailla River (Table 1). The findings in this work agree with the many other authors who noticed that riparian forests may mitigate the effects of agricultural and urban use of the soil. ${ }^{34,35}$

These results support those of other studies that concluded that riparian vegetation retains high yields of phosphorus and sediment. ${ }^{36,37,15}$ However, ${ }^{13}$ noted in some Tucuman Rivers that flow is a more relevant factor influencing Total Solids concentrations than riparian forests quality. These findings have important implications for ecosystem management policies. ${ }^{29}$ The fact that our watersheds do not evidence high pollution values facilitates the identification of preventive measures that would avoid irreversible environmental damage like that observed in the plains. ${ }^{38}$ River water showed physical and chemical characteristics typical of subtropical rivers in the transition flow from a mountain area to a lowland area in spite of intensive soil use in the basins studied. Significant differences observed between dry and rainy periods for some ions are not remarkable being and attributable to rock dilution process. No dragging process for nutrients was observable during rainy periods. However we need to take particular attention monsoonal rainy climate as a main driver for biogeochemical processes in this region. ${ }^{39}$ This study introduces these watersheds as touchstone because they provide information on how the riparian ecosystem works to improve water quality in this area. Integration, management and planning of hydric resources are the principles of water sustainability. Thus, management based on the sophisticated combination of social sciences and ecology would furnish sustainable solutions to the scarcity and degradation of hydric ecosystems. ${ }^{38-46}$

\section{Conclusion}

Basin size, area of agricultural use, type of crop, land slope, and riparian vegetation are extremely important because they influence the physicochemical quality of surface water. Thus, they should be taken into account if we are to minimize the effect of diffuse pollution in the rivers. Although the rivers studied here did not show important signals of degradation, these data are extremely important as they reflect pristine conditions or the first stages of diffuse pollution. We observed when buffer strip between $0-150 \mathrm{~m}$ is affected for land use $(>40 \%)$ shows a diminished filter capacity. Different fertilizers used in subtropical crops affect river water differently but phosphorous must be tracked. Hence, identification of management criteria will help minimize hydric resource degradation in the plains and mitigate the effect of agricultural expansion in mountain areas of steeper slopes.

\section{Acknowledgments}

This study was funded by CONICET (through doctorate fellowships type I and II) and the Projects: PICT_01-12529, CIUNT G213, and CIUNT 26/G309.

We thank C. Molineri, P. Blendiger, L.A. Fernandez, A. Malizia, and A. Izquierdo for comments that improved this manuscript. We are very grateful to J. Blake and B. Reid for manuscript comments and language improvement. We are also grateful to K. Gómez Rojas, P. Powel, R. Moreno, J. Giordano, P. Albornoz Medina, A. Gioia, C. Molineri, G. Aguilera and G. Padilla Bortayro for field assistance.

\section{Conflict of interest}

Authors declare that there is no conflict of interest. 


\section{References}

1. De Vos H, Wester P. The Enabling Environment. Synthesis Report of Theme 3 of E-Forum of the FAO/Netherlands. International Conference on Water for Food and Ecosystems. Netherlands; 2005.

2. Carpenter SR, Caraco NF, Correll DL, et al. Nonpoint pollution of surface waters with phosphorus and nitrogen. Ecological Society of America. 1998;8(3):559-568.

3. Kyriakeas SA, Watzin MC. Effects of adjacent agricultural activities and watershed characteristics on stream macroinvertebrates communities. Journal of the American Water Resources Association. 2006;42:425-441.

4. Sojka M, Siepak M, ZioLa A, et al. Application of multivariate statistical Techniques to evaluation of water quality in the Mała Wełna River (Western Poland). Environmental Monitoring Assessment. 2008;147:159-170.

5. Sharpley AN, Daniel T, Sims T, et al. Agricultural phosphorus and eutrophication. 2nd ed. Washington, USA; 1999.

6. Bennett EM, Carpenter SR, Caraco NF. Human Impact on erodable Phosphorus and Eutrophication: A Global Perspective. Bioscience. 2001;51(3):227-234.

7. Sharpley AN, Daniel T, Sims T, et al. Agricultural Phosphorus and Eutrophication. 2nd ed. Washington, DC; 2003.

8. Barton DR, Taylor WD, Biette RM. Dimensions of riparian buffer strips required to maintain trout habitat in southern Ontario streams. North American Journal Fish Management. 1985;5:364-378.

9. Roth NE, Allan JD, Erickson DL. Landscape influences on stream biotic integrity assessed at multiple spatial scales. Landscape Ecology. 1996;11(3):141-156.

10. Taylor Lovell S, Sullivan WC. Environmental benefits of conservation buffers in the United States: Evidence, promise, and open questions. Agriculture, Ecosystems and Environment. 2006;112:249-260.

11. Garcia AK, Piriz Carrillo V, Gasparri NI, et al. Cambio en la cobertura del suelo En la Cuenca media y alta del Rio Lules. In: La cuenca del Rio Lules, editor. Argentina: una aproximacion multidisciplinaria a su complejidad EDUNT; 2011;111-135.

12. Fernandez HR, Romero F, Dominguez E. Intermountain Basins use in Subtropical Regions and their influences on Benthic Fauna. River Research Applications. 2009;25:181-193.

13. Liu X, Zhang X, Zhang M. Major factors influencing the efficacy of vegetated buffers on sediment trapping: A Review and Analysis. Journal Environmental Quality. 2008;37:1667-1674.

14. Diebel MW, Maxted JT, Robertson DM, et al. Landscape Planning for Agricultural Nonpoint Source Pollution Reduction III: Assessing Phosphorus and Sediment Reduction Potential. Environmental Management. 2009;43(1):69-83.

15. Diebel MW, Maxted JT, Robertson DM, et al. Landscape Planning for Agricultural Nonpoint Source Pollution Reduction III: Assessing Phosphorus and Sediment Reduction Potential. Environmental Management. 2009;43(1):69-83.

16. Hunzinger H, Brown AD, Grau HR. La precipitacion Horizontal: su importancia para el bosque y a nivel de cuenca en la sierra. In: de San Javier, Tucuman, editors. Investigación, Conservación y Desarrollo en las selvas subtropicales de montana. Argentina; 1995:53-58.

17. Grau A, Brown AD. Development threats to biodiversity and opportunities for Conservation in the mountain ranges of the upper Bermejo River Basin, NW Argentina and SW Bolivia. Ambio. 2000;29(7):445-450.

18. Ianni E, Geneletti D. Applying the Ecosystem Approach to Select Priority Areas for Forest Landscape Restoration in the Yungas, Northwestern, Argentina. Environmental Management. 2010;46(5):748-760.
19. Breiman L. Random Forests. Machine Learning. 2001;45:5-32.

20. Liaw A, Wiener M. Classification and regression by random forest. $R$ News. 2002;2(3).

21. Pal M. Random forest classifier for remote sensing classification. International Journal Remote Sensing. 2005;26:217-222.

22. Gislason PO, Bendiksson JA, Sveinsson JR. Random forest for land cover classification. Pattern Recognition Letter. 2006;27:294-300.

23. Cutler DR, Beard ETC, Cutler A, et al. Random Forest for classification in ecology. Ecology. 2007;88(11):2783-2792.

24. APHA. American Public Health Association.18th ed. Standard Methods for the Examination of Water and Wastewater. New York, USA; 1992.

25. IRAM. Norma 29012-6. Calidad ambiental-Calidad del agua. Muestreo. Parte 6: Directivas para el muestreo enriosy cursos de agua. 1998.

26. IRAM. Norma 29012-14. Calidad ambiental. Calidad del agua. Muestreo. Parte 14: Directivas sobre el aseguramiento de la calidad del muestreo y manipulación delagua. 2003.

27. Gregory SV, Swanson FJ, McKee A, et al. An ecosystem perspective of riparian zones: focus on links between land and water. Bioscience. 1991;41:540-551.

28. Jones KL, Poole GC, Meyer JL, et al. Quantifying expected ecological response to natural resource legislation: a case study of riparian buffers, aquatic habitat, and trout populations. Ecology and Society. 2006;11(2):15

29. Lee P, Smyth C, Boutin S. Quantitative review of riparian buffer width guidelines from Canada and the United States. Journal of Environmental Management. 2004;70:165-180.

30. Correll DL. Principles of planning and establishment of buffer zones. Ecological Engineering. 2005;24:433-439.

31. Chang CL, Kuan WH, Lui PS, et al. Relationship between landscape characteristics and surface water quality. Environment Monitoring Assessment. 2008;147:57-64.

32. Romero VF, Fernandez HR, Manzo V, et al. Estudio integral de la cuenca del rio Lules (Tucuman): Aspectos biológicos. In: Fernandez HR, HM Barber, editors. La cuenca del Rio Lules: una aproximación multidisciplinaria a su complejidad. 2011:97-110.

33. Quiroga PA, Julia JP. Estudio de una cuenca de rio subtropical de montana: pautas para su gestion ecosistemica. La cuenca del Rio Lules: una aproximacion multidisciplinaria a su complejidad. Argentina; 2011. p. 1-16.

34. Allan J D, Castillo, Maria M. Stream Ecology, Structure and function of running waters. Netherland: Springer; 2007.

35. Wasson JG, Villeneuve B, Iltal A, et al. Large-scale relationships between basin and riparian land cover and the ecological status of European rivers. Freshwater Biology. 2010;55(7):1465-1482.

36. Sweeney BW. Streamside forest and the physical, chemical, and trophic characteristics of Piedmont streams in eastern North America. Water Science and Technology. 1992;26(12):2653-2673.

37. Sweenwey BW, Bott TL, Jackson JK, et al. Riparian deforestation, stream narrowing and loss of stream ecosystem services. Proceedings of the National Academy of Sciences. 2004;101(39):14132-14137.

38. Le Roy Poff N, Richter BD, Grayman WM, et al. Water Resources and Sustainable Aquatic Ecosystems: A Vision for 2050. Toward a sustainable water future: visions for 2050 / sponsored by Emerging and Innovative Technology Committee, Environmental and Water Resources Institute (EWRI) of the American Society of Civil Engineers; 2012:175-186.

39. Mesa LM. Effect of spates and land use on macroinvertebrate community in Neotropical Andean streams. Hydrobiologia. 2010;641:85-95. 
40. Baron JS, Poff NL, Angermeier PL, et al. Meeting ecological and societa needs for freshwater. Ecological Applications. 2002;12(5):1247-1260.

41. Chaves PS. Image-based atmospheric corrections revisited and improved. Photogrammetric engineering and Remote sensing. 1996;62:1025-1036.

42. EPA. National Management Measures to Control Nonpoint Source Pollution from Hydromodification. Environmental Protection Agency (EPA), Office of Water, EPA 841-B-07-002. United States of America; 2007.

43. Hoffmann C Chr, Kronvang B, Audet J. Evaluation of nutrient retention in four restored Danish riparian wetlands. Hydrobiologia. 2011;674:524.
44. Mayer PM, Reynolds SK, McCutchen MD, et al. Meta-Analysis of Nitrogen Removal in Riparian Buffers. Journal Environmental Quality. 2007;36(4):1172-1180.

45. Robertson LN, Troedson RJ. Cane farming to improve water quality Proceedings of a workshop held at the Mercure Inn, Townsville, 22 August 2003, SRDC Tech. Report 1/2004. Sugar Research and Development. Brisbane, Australia; 2004;40.

46. Song C, Woodcock CE, Seto $\mathrm{KC}$, et al. Classification and Change Detection Using Landsat TM Data: When and How to Correct Atmospheric Effects? Remote Sensing of Environment. 2001;75:230 244. 